\title{
Autologus Hematopoeitic Stem Cell Transplant: Horizon 2020
}

Raut SS $^{*}$ and Shah SA ${ }^{2}$

${ }^{1}$ Consultant Medical Oncologist, HCG-Ranchi, Ex Resident Doctor At Gujarat Cancer And Research Institute, Ahmedabad, India

${ }^{2}$ Unit Head Of Bone Marrow Transplant And Associate Professor, Gujarat Cancer Research Institute, India

\begin{abstract}
Autologus stem cell transplant (ASCT) has evolved over last 5 decades a lot. There are enormous advances in the technique right from mobilization, collection, counting of stem cells to preservation, conditioning and peritransplant care. By the end of this decade we feel necessity to explore the scope and update the details and minutes of ASCT particularly in oncology grossly as well as disease-wise. We delineate the basics of the procedure and advances till date. Also we aimed to summarise the implementation of these advances in India by analyzing the data and information in published articles. This may further help physicians to understand the complex procedure with simplicity and may guide the research workers and authors as reference tool.
\end{abstract}

Keywords: Autologus stem cell transplant; ASCT; Cancer; India

\section{Introduction}

Hematopoetic stem cell transplant (HSCT) is exponentially growing in India [1-4]. Cheaper cost is the main reason behind this rise. There are 3 types of HSCT according to the source of stem cells viz. autologus stem cell transplant (ASCT) where the source is oneself, allogenic stem cell transplant (Allo SCT) where the source is different person and syngenic stem cell transplant where the source is identical twin.

High dose chemotherapy (HDCT) and radiotherapy (RT) is used to ablate the bone marrow producing a fatal marrow aplasia, which is salvaged by ASCT. ASCT also helps to decrease the tumour cell burdon to the minimal, thus giving a prolonged progression free survival (PFS). ASCT does not involve long term immunosuppression or delayed immune reconstitution. Elderly age was a limitation to access of allogenic transplant, which lead to invention of ASCT. Table 1 shows gross difference between ASCT and Allo SCT.

\section{Hematopoetic stem cells (HPSC)}

These are CD34 expressing cells present in spongy bone marrow $(0.5-1 \%)$ [e.g. pelvic bones, ribs, skull, spine] and in circulating blood $(0.05 \%-0.1 \%)$ [1-4]. These also express human leukocyte antigen (HLA) antigens, but lack blood group antigens. They have the capacity of engraftment and differentiation into erythrocytes, leukocytes and platelets.

Phases of ASCT: ASCT includes various processes like Collection, Cryopreservation, HDCT, Thawing, stem cell infusion and Supportive care.

Limitations: ASCT is discouraged in those with Karnofsky score $<70$, LVEF $<40 \%$, Compromised FEV1, DLCO $<40 \%$ of predicted normal, Creatinine $>3 \mathrm{mg} / \mathrm{dl}$, heavily pretreated patients, and Chemorefractory patients. Table 2 shows checklist for pretransplant workup before posting any patient for ASCT.

Counseling: Family meeting before HSCT is necessary to counsel and educate regarding role of relatives accompanying inside the bone marrow transplant room and those visiting from outside. Counseling should also be done for fertility preservation and sperm banking. Half of the patients undergoing ASCT are those having multiple myeloma. Table 3 shows the prevalent indications of ASCT in clinical practice.

Insertion of catheter: A double lumen catheter (DLC) is inserted in jugular or sublclavian vein under local anesthesia. This serves both for purpose of collection and intravenous access for stem cell transplantation. The catheter placement is confirmed by chest x-ray and the insertion site is maintained clean and dry with regular change of dressings along with flushing. Catheter care may require analgesics, and training to inform signs of symptoms of infection like fever, redness, swelling, drainage, increased tenderness. Catheter is removed after the HSCT at the time of discharge.

\section{Collection}

Hematopoetic stem cells (HPSC) for ASCT can be collected either from bone marrow (BM) or peripheral blood (PBSC). They are viable for 5 to 7 days at 2 to $4^{\circ} \mathrm{C}$. For long term preservation, they can be preserved in a balanced salt solution with cryoprotectant (e.g. DMSO, dimethyl sulfoxide) in liquid nitrogen. Bone marrow (BM) collection for stem cells usually should have the volume about 10 to $15 \mathrm{ml} / \mathrm{kg}$ patient weight (1000 $\mathrm{ml}$ approx). Table 4 shows the required quantity and preservation techniques of stem cells during ASCT.

\section{Mobilization}

HPSC are mobilized either with filgrastim (cytokine only) on outpatient basis or low dose cyclophosphamide (chemo mobilization) [1-4]. Filgrastim may cause bone pains and require analgesics, plenty of liquids and rest. Low dose chemotherapy (cyclophospamide) based mobilisation requires antiemetics and mesna for bladder protection. One need to be aware of cytotoxicity of mesna also which manifests as cytopenia, fever, chills, cough, hematuria.

Plerixafor recently used works through disrupting the bond of chemoreceptor type 4 and stromal derived factor-1-alpha, thus moving progenitor cells to peripheral blood. In heavily pretreated patients where cytokine only based mobilization is insufficient, chemotherapy or plerixafor based mobilizations may be preferred. Apheresis may be

*Corresponding Author: Raut SS, 101/102, Laxmi Golden Palm, Opposite Telco Colony Lane No. 8, Dattanagar, Jambhulwadi Road, Ambegaon Khurd, Pune 411046. India, Tel: +91 9099407702; E-mail: shriniatbj@yahoo.co.in

Received May 10, 2019; Accepted May 20, 2019; Published May 31, 2019

Citation: Raut SS, Shah SA (2019) Autologus Hematopoeitic Stem Cell Transplant Horizon 2020. J Blood Lymph 9: 245. doi: 10.4172/2165-7831.1000245

Copyright: () 2019 Raut SS, et al. This is an open-access article distributed under the terms of the Creative Commons Attribution License, which permits unrestricted use, distribution, and reproduction in any medium, provided the original author and source are credited. 


\begin{tabular}{|c|c|c|}
\hline & ASCT & Allo SCT \\
\hline Source of stem cells & Self & Donor (Matched related/unrelated) \\
\hline GVHD & No & Yes \\
\hline Immunosuppressive therapy & Not required & Required \\
\hline Transplant related mortality (TRM) & Less than $3 \%$ generally (2-5\%) & More than $10 \%$ \\
\hline Replacement of marrow & Partial & Complete \\
\hline Tumour contamination of graft & Yes & No \\
\hline Disease recurrence & More chances & Less chances \\
\hline Viral infections & Less & More \\
\hline Prior chemotherapy and radiation & Affects stem cell collection & Not applicable \\
\hline $\begin{array}{l}\text { Risk of myelodysplasia from marrow injury due to } \\
\text { chemotherapy }\end{array}$ & More & Less \\
\hline Age criteria & $<70$ years generally & $<55$ years generally \\
\hline Time lag for donor identification & No & Yes, if no matched sibling \\
\hline Cost in India (average) in rupees & 4 to 7 lakh & $\begin{array}{l}11 \text { to } 17 \text { lakh for matched sibling (MSD), } 21 \text { to } 28 \text { lakh for } \\
\text { unrelated and haploidentical donor HSCT. }\end{array}$ \\
\hline
\end{tabular}

Table 1: Difference between ASCT and Allo SCT [1,4].

\section{Complete history}

\section{CT/Pet CT}

Bone marrow aspiration and biopsy

Lumber puncture

Dental examination

24 hour urine test

Baseline organ functions, biochemistry

HIV, HbsAg, HCV

Pulmonary function test

2 D Echo/Muga scan

Pregnancy test if applicable

Table 2: Pretransplant workup.

\begin{tabular}{|l|c|}
\hline Multiple myeloma & $50-55 \%$ \\
\hline Non Hodgkin lymphoma & $20-25 \%$ \\
\hline Hodgkin lymphoma & $8-9 \%$ \\
\hline Germ cell tumour & $1 \%$ \\
\hline Light chain amylodosis & $0.5 \%$ \\
\hline $\begin{array}{l}\text { Acute myeloid leukemia, predominantly acute } \\
\text { promyelocytic leukemia }\end{array}$ & $0.5 \%$ \\
\hline Acute lymphoblastic leukemia & $0.1 \%$ \\
\hline chronic lymphoblastic leukemia & $0.1 \%$ \\
\hline
\end{tabular}

Table 3: Indications of ASCT practice in percentages [1-4].

required for one to four days and four to five hours each day. Some people get tingling, numbness, leg cramps, light headedness, chills and need to manage symptomatically. In ASCT, the stem cells are collected and stored before the conditioning, unlike Allo SCT where the stem cells can be collected on the day of transplant.

Ancestim (Recombinant human stem cell factor) is a soluble surface molecule on bone marrow stromal cells which is used in conjuction with filgrastim. The doses of mobilizing agents are described in Table 5.

\section{Hospitalization}

Patient is hospitalized usually 2 days to one week before transplant. The countdown of the days starts considering the day of stem cell infusion as "Zero". The preparatory regimen may consist of chemotherapy and/ or radiation. The goal of conditioning is to destroy the cancer cells. Healthy bone marrow also undergoes the simultaneous destruction. The type and amount of chemotherapy depends on the disease. Sideeffects of chemotherapy should be well explained before. Eating normally as long as the patient can is encouraged. Personal

\begin{tabular}{|l|l|}
\hline Source & PBSC or Bone marrow \\
\hline Preservation & With or without preservant \\
\hline Minimum dose of stem cells & 2 million CD34 cells $/ \mathrm{kg}$ recipient body weight \\
\hline Optimal dose of stem cells & $>4$ to 6 million cells $/ \mathrm{kg}$ \\
\hline Short term preservation & At 2 to $4^{\circ} \mathrm{C}$ for 5 to 7 days. \\
\hline Long term preservation & $\begin{array}{l}\text { With a balanced salt solution with cryoprotectant } \\
\text { (e.g. DMSO, dimethyl sulfoxide) in liquid nitrogen }\end{array}$ \\
\hline $\begin{array}{l}\text { Volume of bone marrow } \\
\text { collection }\end{array}$ & $10 / 15 \mathrm{ml} / \mathrm{kg}$ patient weight $(1000 \mathrm{ml}$ approximately) \\
\hline
\end{tabular}

Table 4: Collection of stem cells for ASCT.

\begin{tabular}{|l|l|}
\hline Mobilizing agent & Dose \\
\hline Filgrastim & $\begin{array}{l}10 \mathrm{mcg} / \mathrm{kg} / \text { day SC since 4 days prior to } \\
\text { collection }\end{array}$ \\
\hline $\begin{array}{l}\text { Cyclophosphamide } \\
1-5 \mathrm{gm} / \mathrm{m}^{2}\end{array}$ \\
$\begin{array}{l}\text { Plerixafor (after 4 days of filgrastim and } \\
11 \text { hours prior to apheresis) }\end{array}$ & $\begin{array}{l}0.24 \mathrm{mg} / \mathrm{kg} \mathrm{SC} / \text { day (max } 40 \mathrm{mg} \text { per day) } \\
\text { for upto } 4 \text { consecutive days }\end{array}$ \\
\hline $\begin{array}{l}\text { Ancestim } \\
20 \mathrm{mcg} / \mathrm{kg} / \text { day SC along with filgrastim }\end{array}$ \\
\hline \multicolumn{2}{|c|}{ Table 5: Mobilizing agent and Dose [1-4]. }
\end{tabular}

hygiene should be educated. Light physical activity may be allowed to sleep better and assists cardiac activity and muscle circulation.

Approximately 3 weeks of hospitalization is required for ASCT as compared to four to five weeks for Allo SCT. The setup is usually a HEPA filter unit with private bathrooms for patient use only. It may contain television, telephone to feel as homely as possible. All things should be clean. Facemask can be used. Input and output chart should be recorded including urine and bowel charts. Good oral hygien should be maintained to reduce oral infections and bleeding gums. Hand washing is the key of asepsis. Plants and flowers are not allowed in the unit to prevent fungal and bacterial infections. No sick relatives or live vaccine recipients are allowed to visit the patient. One family member is usually allowed to sleep in the room of patient.

\section{Conditioning}

Most commonly used conditioning regimens for various cancers are as follows: for multiple myeloma single agent melphalan, for lymphoma BEAM (BCNU, etoposide, Ara C, Melphalan) and CBV (cyclophosphomide, BCNU etoposide), for AML BuCy (Busulphan, Cyclophosphamide) or BuMel (busulfan, Melphalan)or BEA (busulfan, etoposide, Ara -C) and for germ cell tumour TICE (Paclitaxel, Ifosfamide, Carboplatin, Etoposide). There are a number of short term as well as long term side effects linked with high dose chemotherapy. Short term side effects are explained in Table 6. 


\begin{tabular}{|l|l|l|}
\hline & Complication & Management \\
\hline 1 & Neutropenia & Filgrastim, antibiotics \\
\hline 2 & Anemia & Packed red cells to maintain hemoglobin greater than $8 \mathrm{gm} \%$ \\
\hline 3 & Thrombocytopenia & Single donor platelets to maintain platelets greater than $10,000 / \mathrm{cmm}$ \\
\hline 4 & Infections & $\begin{array}{l}\text { Isolation, asepsis, hand washing, mask, gloves, gowns, shoe covering, Hepa filters, laminar flow, avoiding sick visitors, } \\
\text { antibiotics, antifungals, antivirals }\end{array}$ \\
\hline 5 & Nausea, vomiting & Antiemetics, fluids electrolyte replacement, total parentral nutrition \\
\hline 6 & Transfusion reactions & Antiallergics, steroids, mannitol, diuretics, antipyretics, irradiation of blood products. \\
\hline 7 & Hepatic venoocclusive disease & Defibrotide \\
\hline 8 & Acute respiratory distress & Antibiotics, fluid electrolyte balance, ventilator support \\
\hline & & \\
\hline
\end{tabular}

Table 6: Short term complications and their management $[1,4]$.

Isolation and asepsis are most important in the neutropenic care for 3 to 4 weeks of hospitalisation. The precautions include avoiding sick visitors, hand washing, mask, gowns, gloves, shoe coverings, Hepa filters and laminar flow [5-9].

\section{Complications of ASCT}

On the day of transplant, infusion reactions like fever, chills, hypotension, chest pain, cough can occur. They are managed like usual blood transfusion reactions.

During engraftment process, bacterial, viral and fungal infections usually pertaining to prolonged grade 4 neutropenia occure. Other side effects of HDCT are nausea, vomiting, fluid electrolyte imbalance, mucositis, malnutrition, bleeding, blood transfusion support, hepatic venoocclusive disease, acute respiratory distress syndrome.

Long term complications are relapse of cancer, leukemia, myelodysplasia, interstitial pneumonitis and hemorrhagic cystitis.

Cytopenia recovers within 3 weeks, the duration of which can be decreased by 4 days with filgrastim. Packed red cells (PRBC) and platelet transfusion (SDP preferably) and other supportive care is required same as management of grade 4 neutropenia. Irradiating all the blood products before transfusion reduces the transfusion associated GVHD. Stem cells never to be irradiated.

Major infections which are gram negative bacteria, gram positive bacteria, clostriadia, herpes and fungi are treated with antibiotics, antivirals, antifungals, growth factors. Hepatic veno-occlusiove disease (tender hepatomegaly, jaundice and fluid retention in first 2 to 3 weeks) and idiopathic pneumonia syndrome, acute respiratory distress (ARDS) are infrequent but not to be missed. Table 7 explains the infection prophylaxis.

Transplant related mortality (TRM) should be minimal (usually $<3 \%)$. Relapses are commoner in ASCT than allo-SCT. Table 8 enlists causes of death in ASCT.

Side effects of radiation are short term (e.g fatigue, skin redness, dryness, fever, nausea, vomiting, diarrhoea, mucositis and headache) and long term (e.g skin cancer, xeroderma, xerosis of mouth, cataracts, pneumonitis).

Chemotherapy can be associated with sterility. Sperm banking or fertilized ova preservation should be advised.

\section{Stem Cell Transplantation (SCT) Proper}

Stem cell infusion is same as blood transfusion. Premedication and antiallergics should be used. Mannitol and diuretics can be used when hemolysis is suspected after stem cell transfusion. The day of stem cell infusion is labelled as day "Zero". Transfusion reactions are managed as same as blood transfusion. Patient may experience the garlic like

\begin{tabular}{|l|l|l|}
\hline & Organism & Prophylaxis \\
\hline 1 & Bacteria & Not routinely used \\
\hline 2 & Fungi & $\begin{array}{l}\text { Fluconazole, posaconazole, voriconazole, } \\
\text { amphotericin B }\end{array}$ \\
\hline 3 & Virus & Acyclovir, Valacyclovir \\
\hline 4 & Pneumocystis jirovaci & Cotrimoxazole \\
\hline 5 & Parasites & Albendazole \\
\hline
\end{tabular}

Table 7: Infection prophylaxis [1-4].

\begin{tabular}{|l|c|}
\hline Primary disease & $65-69 \%$ \\
\hline Infections & $6-8 \%$ \\
\hline Organ failure & $3-4 \%$ \\
\hline Secondary malignancy & $1-2 \%$ \\
\hline Other & $16-18 \%$ \\
\hline
\end{tabular}

Table 8: Causes of death in ASCT $[1,4]$.

odour for some time which is due to the preservatives.

Engraftment day is usually marked by first of 3 consecutive days with absolute neutrophhil count (ANC) $\geq 0.5 \times 10^{9} / \mathrm{L}$ and unsupported platelet count $\geq 20 \times 10^{9} / \mathrm{L}$ on 3 consecutive days. Engraftment occures in 2 weeks with PBSC and in 3 weeks with bone marrow stem cells. Filgrastim reduces duration of severe neutropenia by 2 to 4 days. Blood counts are monitored with daily CBC. There is increased risk of infection with decreased absolute neutrophil count (ANC) below 1000/cmm. This is tide over with supportive antibiotics. Hand washing is critical in asepsis. Anemia is associated with fatigue and thrombocytopenia manifests with bruising, bleeding. Blood component support is required to maintain $\mathrm{Hb}>8 \mathrm{~g} \%$ and platelet $>10,000 \mathrm{cmm}$. Irradiation and Leukocyte-reduced products should be used for prevention of HLA immunization. Severe mucositis impaires feeding and should be managed with total parentral nutrition (TPN).

\section{Discharge advice}

Discharge advice consists of complete diet, personal hygeine, home care explaination which includes cleanliness of patients atmosphere, and avoiding crowded places or sick people. These precautions are recommended till immune reconstitution which takes about 3 months after ASCT. After discharge there is frequent follow up for blood investigations and clinical assessment for signs or symptoms of infection. Post-transplant clinic visits are generally scheduled one to three times a week. Patients are informed to report if fever, chills, catheter problems if catheter is in situ, hematuria, dysuria, chicken pox exposure, diarrhoea, nausea, vomiting, malena, bleeding gums. Outside food should be avoided. Animal contact including pets and birds should be avoided. Travel, public toilets, restaurants, strenous activities should be avoided. Sex is allowed if platelet and total leukocyte counts are normal and there are no sexually transmissible infections in any of the partners. Barriers such as condom are recommeded 
during immunocomromised period. Table 9 lists important points in discharge advice.

\section{Multiple Myeloma (MM)}

Stem cells are viable at 2 to $4{ }^{\circ} \mathrm{C}$ for 5 to 7 days, hence ASCT in MM can be done without use of DMSO [5-24].

Triple drug induction (including novel drugs), early upfront ASCT and maintenance therapy are standard of care in all transplant candidates of myeloma. The dose of melphalan may vary according to age of patient. Tandem ASCT are useful only in those patients who are not in VGPR at the time of first ASCT. ASCT remains useful even in relaspse setting as salvage, in patients with renal dysfunction and even in novel agent era. High risk biology e.g. t( $4 ; 14)$, del(17p) or high $\beta 2$ microglobin have poor prognosis even with ASCT. Though the OS benefit remains controversial, there is definite evidence of CR and EFS benefits. Also, transplant outcomes are better with early ASCT than late ASCT. Pet scan and minimal residual disease (MRD) are increasingly used to enhance ASCT outcomes. Table 10 describes ASCT strategies in myeloma.

\section{Lymphoid malignancies}

Relapsed Hodgkin and relapsed, aggressive non Hodgkin lymphoma (NHL) demonstrate 40\%-55\% cure rate with ASCT [2533]. ASCT is controversial in indolent NHL and T-cell NHL. CBV, BEAM and TBI based regimens are most commonly used conditioning regimens for lymphoma. TBI free conditioning have lower TRM. Chemotherapy or plerixafor based mobilization should be considered in heavily pretreated cases.

Follicular lymphoma (FL), first remission (CR1): The routine use of first line ASCT consolidation in FL is not advisable in the rituximab era. Though ASCT can give more EFS/PFS, it doesn't translate into more overall survival. Also, ASCT is asscociated with increased TRM and higher number of secondary malignancies (GITMO 2008).

Follicular lymphoma (FL), relapsed: Chemosensitive FL patients (CR2) undergoing ASCT achieve long term remissions irrespective of rituximab but its status is controversial due to better outcomes of salvage chemo immunotherapies. ASCT may be occasionally preferred over allo-SCT due to its acceptability and well known security profile. ASCT is best reserved for chemo sensitive, relapsed FL patients who are not candidates for allo-SCT. CIBMTR-2004 retrospective data predicts better OS and EFS with purged ASCT (62\% vs. 55\%).

Transformed FL: ASCT is recommended for transformed FL with non-bulky and chemo sensitive disease.

Mantle cell lymphoma (MCL): Upfront consolidative ASCT in CR1 is standard of care in MCL and 5 year survival with ASCT is 60$70 \%$. ASCT is also recommended for chemo sensitive, relapsed MCL patients, who are not candidates for allo-SCT where 5 year survival is 44\%. Hermine et al (2012) demonstrated near doubled EFS (84 months

\section{Complete diet plan}

Personal hygiene

Follow up schedule and discharge medicines

Catheter care if catheter in situ

Barrier sex

Avoiding crowds

Signs of infection and emergency contact numbers

preventive care like avoiding smoking and tobacco

Table 9: Discharge advise.

\begin{tabular}{|c|c|c|}
\hline & Strategies & Response \\
\hline \multirow[t]{3}{*}{1} & Upfront consolidative ASCT & \\
\hline & Young fit patients ( $200 \mathrm{mg} / \mathrm{m}^{2}$ melphalan) & OS benefit \\
\hline & Elderly patients ( $100-140 \mathrm{mg} / \mathrm{m}^{2}$ melphalan) & OS benefit \\
\hline \multirow[t]{3}{*}{2} & Tandem ASCT & \\
\hline & $\begin{array}{l}\text { For those who are in VGPR at the time of first } \\
\text { ASCT }\end{array}$ & No OS benefit \\
\hline & $\begin{array}{l}\text { Tandem (delayed second) ASCT for those who } \\
\text { are not in VGPR at the time of first ASCT }\end{array}$ & EFS and OS benefit \\
\hline 3. & ASCT on relapse/Salvage ASCT/Second ASCT & OS benefit \\
\hline 4. & $\begin{array}{l}\text { ASCT with advanced renal failure }\left(140 \mathrm{mg} / \mathrm{m}^{2}\right. \\
\text { melphalan) }\end{array}$ & OS benefit \\
\hline 5. & $\begin{array}{l}\text { ASCT in the era of novel agents with triplet } \\
\text { induction }\end{array}$ & EFS benefit \\
\hline 6. & $\begin{array}{l}\text { Lenalidomide/ Bortezomib } \\
\text { maintenance replaces thalidomide } \\
\text { maintenance }\end{array}$ & $\begin{array}{l}\text { OS benefit, } 25 \% \text { risk } \\
\text { reduction in mortality } \\
\text { but threefold increase in } \\
\text { second malignancies }\end{array}$ \\
\hline 7. & Oral ixazomib maintenance -2 years & PFS benefit \\
\hline 8. & MRD after ASCT & Predictor of EFS \\
\hline 9. & PET CT after ASCT & Predictor of EFS \\
\hline 10. & Plerixafor in mobilization & $\begin{array}{l}\text { Post heavy chemotherapy } \\
\text { mobilization }\end{array}$ \\
\hline 11. & Propylene glycol free formulation of Melphalan & Higher bioavailability \\
\hline
\end{tabular}

vs. 49 months) with marked OS advantage with R-DHAP induction ASCT. Rituximab and addition of cytarabine in induction improved the OS. However mantle cell leukemia should be treated with allo-SCT.

Waldenstrom macroglobulinemia (WM): ASCT should be considered in relapsed chemosensitive WM patients who have received 2 or 3 different therapies, 5 year PFS and OS being $40 \%$ and $68 \%$ respectively.

Marginal zone lymphoma (MZL): In relapsed, chemosensitive MZL, ASCT should be considered though the data is very scant.

Chronic lymphocytic leukemia (CLL)/small lymphocytic lymphoma (SLL): ASCT is not helpful in CLL/SLL.

Diffuse large B cell lymphoma (DLBCL), first remission: ASCT is not indicated in first line in DLBCL due to very good outcomes of chemo immunotherapy but in double hit lymphoma treated with $\mathrm{RCHOP}$ it is recommended.

DLBCL, relapsed disease: ASCT is standard treatment for relapsed, chemo sensitive DLBCL. CORAL study (2010) established the role of ASCT (EFS 53\%) for relapsed DLBCL after RICE/ RDHAP salvage regimens [23].

Burkitt lymphoma (BL): ASCT is not required in BL in first CR due to curative chemo immunotherapy. In relapsed chemo sensitive BL, ASCT gives 3 year PFS of $30 \%$.

Hodgkin lymphoma (HL), relapsed or primary refractory: ASCT seems curative and standard therapy in relapsed chemo sensitive HL as well as primary refractory HL. CIBMTR $(2001,1999)$ data shows that patients in CR2 have better prognosis and $40 \%$ of primary refractory patients can be benefited by ASCT [22].

T cell lymphoma (TCL): ASCT is recommended in T cell NHL as upfront consolidation except in ALK positive anaplastic large cell lymphoma. ASCT is also preferred for relapsed, chemo sensitive TCL patients (CR2) who are not candidates for allo-SCT. 
Post-transplant maintenance therapies for lymphoma: Rituximab maintenance has shown to increase OS in MCL but not in FL or DLBCL. Also brentuximab is approved for post ASCT consolidation and maintenance in high risk $\mathrm{HL}$.

PET scan in ASCT: PET negative state before and after ASCT predict improved ASCT outcomes.

Rarer plasma cell dyscrasias: HDCT with melphalan has been effective in Light chain amyloidosis, ligh chain deposition disease and POEMS syndrome but randomized clinical trials are not available.

\section{Acute myeloid leukemia (AML)}

Patients of AML with favorable and intermediate risk cytogenics can be considered for ASCT after induction therapy if suitable donor is not available [34].

\section{Acute lymphoblastic leukemia (ALL)}

Routine ASCT in ALL in first line as consolidation or maintenance or in relapsed patients is not recommended [35]. Some older studies have demonstrated similar EFS with ASCT as compared to allo-SCT in selected patients. However Philadelphia chromosome positive patients receiving tyrosine kinase inhibitors (TKI) with chemotherapy can be considered for ASCT when suitable donors are not available. ASCT is an option when allograft donor is notavailable.

\section{Germ cell tumour (GCT)}

ASCT is potentially curative in high risk GCT relapsed after or refractory to first line chemotherapy regimens [36]. Carboplatin and etoposide are used in conditioning of GCT.Table 11 highlights role of ASCT in non-myeloma cancers at present.

Late complications of ASCT: ASCT reduces life expectancy as compared to healthy population and there is increased risk for opportunistic infections, iron overload, endocrine disturbances, osteoporosis and second malignancies. Table 12 describes monitoring for late complications of ASCT.

Preventive maintenance after transplant: One should follow healthy practices i.e. abstaining tobacco and alcohol, having healthy foods, exercise and regular sunscreen use. Blood tests-Annual CBC, biochemistry, blood glucose level, serum lipid levels, thyroid hormone levels.

ASCT can increase the risk of secondary cancers e.g. skin cancer, head and neck cancer, breast cancer, thyroid cancer (papillary thyroid carcinoma), and brain cancers (astrocytomas). The risk of hepatocellular carcinoma (HCC) is increased in patients having hepatitis $\mathrm{C}$ infection.

\section{Indian Scenario}

'Indian Stem Cell Transplant Registry (ISCTR)', a nonprofit organization established in 2004 compiles and maintains the database of HSCT activities in various centres in India. By 2020 there will be near 100 centres carrying out HSCT in India [37-65]. Though the population of India is several times more than USA, the HSCT activity in India is 10 times less than USA. This is the failure to deliver standard of care curative treatment strategies in cancer. By 2020, India may cross 20,000 transplants. Out of these grossly $60 \%$ estimated to be allo-SCT, the rest $40 \%$ being ASCT. Half of all ASCT are generally MM, followed by mature B cell NHL andHL.

ASCT costs 4 to 7 lakh in India and the cost is 20 times more in developed nations. Hence, India has a good potential for medical tourism in HSCT especially for Middle East countries and South Asian countries.

Gram negative organisms dominate in cultures in India, as compared to gram positive organisms in western countries. A few reports from India show good outcome of HSCT even in compromised infrastructure e.g. without HEPA filters. Worldwide, the trend of "ASCT with bone marrow proper" collection has been shifted to "peripheral blood stem cell based ASCT" with comparable efficacy.

\begin{tabular}{|c|c|c|c|}
\hline \multirow[t]{3}{*}{1} & \multirow[t]{3}{*}{ Follicular lymphoma } & First remission & Not recommended \\
\hline & & Relapsed & Only in chemosensitive \\
\hline & & Transformed follicular lymphoma & Nonbulky chemosensitive \\
\hline \multirow[t]{3}{*}{2} & \multirow[t]{3}{*}{ Mantle cell lymphoma } & First remission & Standard \\
\hline & & Relapsed & Only in chemosensitive \\
\hline & & Refractory & Not recommended \\
\hline \multirow[t]{2}{*}{3} & Waldenstrom macroglobulinemia & First remission & No data \\
\hline & & Relapsed & Only in chemosensitive who had received 2 or 3 therapies. \\
\hline \multirow[t]{2}{*}{4} & Marginal zone lymphoma & First remission & Not recommended \\
\hline & & Relapsed & Only in chemosensitive \\
\hline 4 & SLL & & Not recommended \\
\hline \multirow[t]{2}{*}{6} & DLBCL & First remission & Recommended in double-hit DLBCL treated with RCHOP. \\
\hline & & Relapsed & Standard of care in chemosensitive disease. \\
\hline \multirow[t]{2}{*}{7} & BURKITT Iymphoma & First remission & Not recommended \\
\hline & & Relapsed & Only in chemosensitive \\
\hline \multirow[t]{2}{*}{8} & Hodgkin lymphoma & Relpased & Standard of care \\
\hline & & Primary refractory & Standard of care \\
\hline \multirow[t]{2}{*}{9} & T cell lymphoma & First remission & Except in ALK positive anaplastic large cell NHL \\
\hline & & Relapsed & Only in chemosensitive and not suitable for allogenic SCT \\
\hline 10 & AML & First CR & Favourable and intermediate cytogenetic risk \\
\hline 11 & ALL & & When allograft donor not available. \\
\hline \multirow[t]{3}{*}{12} & Germ cell tumour & First remission & Not recommended \\
\hline & & Relapsed & Optional, potentially curative, controversial \\
\hline & & Refractory & Early referral recommended \\
\hline
\end{tabular}

Table 11: Strategy of ASCT in malignancies other than myeloma and recommendations [24-36]. 
Citation: Raut SS, Shah SA (2019) Autologus Hematopoeitic Stem Cell Transplant: Horizon 2020. J Blood Lymph 9: 245. doi: 10.4172/21657831.1000245

Page 6 of 8

\begin{tabular}{|l|l|l|}
\hline & Complication & Measures \\
\hline 1 & Psychological disturbances & Counselling, Anxiolytics, antidepressants, psychotherapy \\
\hline 2 & Cataracts & Annual ophthalmic check up \\
\hline 3 & Thyroid disorders & 6 monthly T3, T4, TSH \\
\hline 4 & Lung damage & Pulmonary function tests \\
\hline 5 & Infection & Hand wash \\
\hline 6 & Infertility & Ova and sperm preservations, infertility clinics \\
\hline 7 & Osteoporosis & Vitamin D and calcium supplements, exercise, weight bearing, DEXA scan \\
\hline 8 & Skin rashes & Antivirals for herpetic infections, sunscreens, avoiding direct sunlight \\
\hline 9 & Cardiac disorders & Interval 2 D echo \\
\hline 10 & Second malignancies & Annual pap smear, breast examinations and mammography, viral markers, colonoscopy, stool occult blood \\
\hline 11 & Dental complications & Good oral hygiene, avoid dental procedures in first 6 months, routine dental examinations \\
\hline 12 & Growth disturbances & Regular height and weight, if necessary growth hormone levels \\
\hline 13 & Relapse of cancer & CBC, scheduled imaging as necessary \\
\hline 14 & Hemorrhagic cystitis & Watch for hematuria \\
\hline & & . \\
\hline
\end{tabular}

Table 12: Long term complications and their management $[1,4,65]$

\begin{tabular}{|c|c|c|c|}
\hline Reference & Analysis & Institution & Contribution \\
\hline $\begin{array}{l}\text { Kulkarni and George } \\
{[60]}\end{array}$ & $\begin{array}{l}\text { Access to hematopoietic stem-cell } \\
\text { transplantation in India }\end{array}$ & $\begin{array}{l}\text { Christian Medical College, Vellore, } \\
\text { Tamil Nadu, }\end{array}$ & $\begin{array}{l}\text { Addresses multipronged approach that includes increasing } \\
\text { the number and improving minimum standards for HSCT } \\
\text { centers, reducing overall costs associated with HSCT, and } \\
\text { helping patients with financial support for HSCT. }\end{array}$ \\
\hline Das, et al. [61] & $\begin{array}{l}\text { Establishing Hematopoietic Stem Cell } \\
\text { Transplant Unit in Resource Limited Setting: }\end{array}$ & $\begin{array}{l}\text { Cancer Research Institute, Swami } \\
\text { Rama Himalayan University, } \\
\text { Dehradun, }\end{array}$ & $\begin{array}{l}\text { Criticism on criteria of qualified doctor and staff. Criticism on } \\
\text { restriction on rare indications, not defining criteria and timing } \\
\text { of establishing HSCT unit. }\end{array}$ \\
\hline Jotwani [63] & $\begin{array}{l}\text { National Guidelines for Stem Cell Research } \\
2017\end{array}$ & $\begin{array}{l}\text { Indian Council of Medical Research } \\
\text { and Department of Biotechnology }\end{array}$ & $\begin{array}{l}\text { Any stem cell use in patients, other than that for } \\
\text { hematopoietic stem cell reconstitution for approved } \\
\text { indications, is investigational at present. Every use of stem } \\
\text { cells in patients outside an approved clinical trial is unethical } \\
\text { and shall be considered as malpractice }\end{array}$ \\
\hline Prinja, et al. [51] & Cost effectiveness of ASCT & PGI Chandigarh & $\begin{array}{l}\text { Cost effectiveness of ASCT improved with early detection and } \\
\text { initiation of treatment. }\end{array}$ \\
\hline Raut, et al. [52] & ASCT in HD & GCRI Ahmedabad & DFS $65 \%$ and OS $70 \%$ \\
\hline Kumar, et al. [53] & ASCT for myeloma :long term results & AlIMS New Delhi & $\begin{array}{l}\text { CR following ASCT associated with good long term outcome. } \\
\text { PFS : } 32 \text { months, OS : } 85.5 \text { months }\end{array}$ \\
\hline Pandit, et al. [65] & $\begin{array}{l}\text { Changes in bone mineral density and bone } \\
\text { turnover markers in patients HSCT }\end{array}$ & $\begin{array}{l}\text { Military Hospital, Shillong, } \\
\text { Meghalaya, }\end{array}$ & $\begin{array}{l}\text { A significant bone loss is observed at } 6 \text { months in patients } \\
\text { with post-HSCT predominantly at cortical bone. There is } \\
\text { recovery at } 12 \text { months posttransplant except at Ward's } \\
\text { triangle. }\end{array}$ \\
\hline Raut, et al. [54] & $\begin{array}{l}\text { safety of eltrombopag in post HSCT } \\
\text { thrombocytopenia }\end{array}$ & GCRI Ahmedabad & $\begin{array}{l}25-50 \mathrm{mg} \text { OD Eltrombopag for post-HSCT thrombocytopenia } \\
\text { is well tolerated, appears efficacious and offers transfusion } \\
\text { independence. }\end{array}$ \\
\hline Shah C A, et al. [41] & data from western India & Apollo hospital, Gandhinagar & comparability with international standards \\
\hline Shah CA, et al. [55] & $\begin{array}{l}\text { ASCT in MM in nonuniversity hospital of } \\
\text { developing country }\end{array}$ & Apollo hospital, Gandhinagar & ASCT feasible in nonuniversity hospital \\
\hline Sharma, et al. [39] & cost of HSCT in India & $\begin{array}{l}\text { BLK superspeciality hospital New } \\
\text { Delhi }\end{array}$ & ASCT cost 12500 USD (10331-39367) \\
\hline Kumar, et al. [52] & CR after ASCT in MM & AlIMS New Delhi & $\begin{array}{l}\text { those who receive one line of induction therapy before } \\
\text { transplant have superior outcome, }\end{array}$ \\
\hline Kayal, et al. [47] & $\begin{array}{l}\text { ASCT using noncryopreserved peripheral } \\
\text { blood stem cells }\end{array}$ & AlIMS New Delhi & Noncryopreserved PBSC is simple, effective and safe. \\
\hline Mukhopadhyay [42] & data from Eastern India & NCRI Kolkata & ASCT cost 3-4 lakhs \\
\hline Kumar L, et al. [49] & ASCT for $\mathrm{HL}$ and $\mathrm{NHL}$ & AlIMS New Delhi & $\begin{array}{l}\text { pretransplant chemosensitive disease and CR after transplant } \\
\text { had better survival }\end{array}$ \\
\hline Pandya, et al. [62] & Ethics of stem cell transplant in India & $\begin{array}{l}\text { Jaslok Hospital and Research } \\
\text { Centre, Mumbai }\end{array}$ & Raised question on irrational use of stem cells. \\
\hline Chandy, et al. [37] & Stem Cell Transplantation In India. & CMC Vellore & First comprehensive Indian data on stem cell transplantation \\
\hline
\end{tabular}

Table 13: summarizing latest scientific reports with their inputs in ASCT activity in India [37-65].

Early referrals should be encouraged along with development of infrastructure (Table 13)

\section{Conclusion}

By 2020 India is projected to a growth about 9 billion dollars in medical tourism. India is preferred medical hub even by UK, Russia and USA due to low cost of treatment. South Asian and Middle East countries prefer Indian healthcare due to poor infrastructure in respective countries and close proximity to India. Chennai, Kolkata, Mumbai, Hyderabad, and Delhi-NCR are popular destinations for treatment for patients abroad. There are approximately 33 JCI (Joint commission international) accredited hospitals in India. Medical visa on arrival scheme allows foreign patients to stay about a month (extendable upto 6 months) which decreases the difficulty of foreign 
patients taking treatment in India. Table 13 summarises contributing literature in ASCT from recent past in India.

\section{Conflict of Interest}

Author declared no conflicts of interest in any form.

\section{References}

1. Lazarus HM, Hamadani H, Hari PN (2018) Autologus Hematopoetic cell transplantation. Devita, Hellman and Rosemberg's Cancer Principles \& practice of oncology (11thedn).

2. Worldwide Network for Blood and Marrow Transplantation. Media Fact Sheet: 1 Million Blood Stem Cell Transplants Worldwide. WBMT.

3. Santos GW (1983) History of bone marrow transplantation. Clin Haematol 12: 611-639.

4. Hamadani M (2014) Autologous hematopoietic cell transplantation: an update for clinicians. Ann Med 46: 619-632.

5. Cavo M, Beksac M, Dimopoulos MA, Pantani L, Gay F, et al. (2016) Intensification therapy with bortezomib-melphalan-prednisone versus autologous stem cell transplantation for newly diagnosed multiple myeloma: an intergroup, multicenter, phase III study of the European Myeloma Network (EMN02/HO95 MM Trial). Blood 128: 673.

6. Gay F, Oliva S, Petrucci MT, Conticello C, Catalano L, et al. (2015) Chemotherapy plus lenalidomide versus autologous transplantation, followed by lenalidomide plus prednisone versus lenalidomide maintenance, in patients with multiple myeloma: a randomised, multicentre, phase 3 trial. Lancet Oncol 16: $1617-1629$

7. Palumbo A, Cavallo F, Gay F, Raimondo FD, Yehuda DB, et al. (2014) Autologous transplantation and maintenance therapy in multiple myeloma. $N$ Engl J Med 371: 895-905.

8. Attal M, Lauwers-Cances V, Hulin C, Leleu X, Caillot D, et al. (2017) Lenalidomide, bortezomib, and dexamethasone with transplantation for myeloma. N Engl J Med 376: 1311-1320.

9. Usmani SZ, Crowley J, Hoering A, Mitchell A, Waheed S, et al. (2013) Improvement in long-term outcomes with successive Total Therapy trials for multiple myeloma: are patients now being cured? Leukemia 27:226-232.

10. Gay F, Oliva S, Petrucci MT, Montefusco V, Conticello C, et al. (2017) Autologous transplant vs oral chemotherapy and lenalidomide in newly diagnosed young myeloma patients: a pooled analysis. Leukemia 31:1727-1734.

11. Palumbo A, Bringhen S, Bruno B, Falcone AP, Liberati AM, et al. (2010) Melphalan $200 \mathrm{mg} / \mathrm{m} 2$ versus melphalan $100 \mathrm{mg} / \mathrm{m} 2$ in newly diagnosed myeloma patients: a prospective, multicenter phase 3 study. Blood 115: 1873 1879.

12. Sharma M, Zhang MJ, Zhong X, Abidi MH, Akpek G, et al. (2014) Older patients with myeloma derive similar benefit from autologous transplantation. Biol Blood Marrow Transplant 20: 1796-1803.

13. Glavey SV, Gertz MA, Dispenzieri A, Kumar S, Buadi F, et al. (2013) Long-term outcome of patients with multiple [corrected] myelomarelated advanced renal failure following auto-SCT. Bone Marrow Transplant 48: 1543-1547.

14. Attal M, Lauwers-Cances V, Marit G, Caillot D, Moreau P, et al. (2012) Lenalidomide maintenance after stem-cell transplantation for multiple myeloma. N Engl J Med 366: 1782-1791.

15. McCarthy PL, Owzar K, Hofmeister CC, Hurd DD, Hassoun H, et al. (2012) Lenalidomide after stem-cell transplantation for multiple myeloma. $\mathrm{N}$ Engl $\mathrm{J}$ Med 366: 1770-1781.

16. McCarthy PL, Holstein SA, Petrucci MT, Richardson PG, Hulin C, et al. (2017) Lenalidomide maintenance after autologous stem-cell transplantation in newly diagnosed multiple myeloma: a meta-analysis. J Clin Oncol 35:3279-3289.

17. Stadtmauer EA, Pasquini MC, Blackwell B, Knust K, Bashey A, et al. (2016) Comparison of autologous hematopoietic cell transplant (autoHCT), bortezomib, lenalidomide (Len) and dexamethasone (RVD) consolidation with Len maintenance (ACM), tandem Autohct with Len maintenance (TAM) and Autohct with Len maintenance (AM) for up-front treatment of patients with multiple myeloma (MM). Blood 128: LBA-1.

18. Cavo M, Gay FM, Patriarca F, Zamagni E, Montefusco V, et al. (2017) Double autologous stem cell transplantation significantly prolongs progression-free survival and overall survival in comparison with single autotransplantation in newly diagnosed multiple myeloma: an analysis of phase 3 EMN02/HO95 study. Blood 130: 401.

19. Moreau P, Attal M, Caillot D, Macro M, Karlin L, et al. (2017) Prospective evaluation of magnetic resonance imaging and [18F]fluorodeoxyglucose positron emission tomography-computed tomography at diagnosis and before maintenance therapy in symptomatic patients with multiple myeloma included in the IFM/DFCI 2009 trial: results of the IMAJEM study. J Clin Oncol 35: 2911 2918.

20. Kumar S, Giralt S, Stadtmauer EA, Harousseau JL, Palumbo A, et al. (2009) Mobilization in myeloma revisited: IMWG consensus perspectives on stem cell collection following initial therapy with thalidomide-, lenalidomide-, or bortezomib-containing regimens. Blood 114: 1729-1735.

21. Uy GL, Costa LJ, Hari PN, Zhang MJ, Huang JX, et al. (2015) Contribution of chemotherapy mobilization to disease control in multiple myeloma treated with autologous hematopoietic cell transplantation. Bone Marrow Transplant 50: 1513-1518.

22. Michaelis LC, Saad A, Zhong X, Le-Rademacher J, Freytes CO, et al. (2013) Salvage second hematopoietic cell transplantation in myeloma. Biol Blood Marrow Transplant 19: 760-766

23. Cook G, Ashcroft AJ, Cairns DA, Williams CD, Brown JM, et al. (2016) The effect of salvage autologous stem-cell transplantation on overall survival in patients with relapsed multiple myeloma (final results from BSBMT/UKMF Myeloma X Relapse [Intensive]): a randomised, open-label, phase 3 trial. Lancet Haematol 3: e340-e351.

24. D'Souza A, Dispenzieri A, Wirk B, Zhang MJ, Huang J, et al. (2015) Improved outcomes after autologous hematopoietic cell transplantation for light chain amyloidosis: a Center for International Blood and Marrow Transplant Research Study. J Clin Oncol 33: 3741-3749.

25. Casulo C, Friedberg JW, Ahn KW, Flowers C, DiGilio A, et al. (2018) Autologous transplantation in follicular lymphoma with early therapy failure: a National LymphoCare Study and Center for International Blood and Marrow Transplant Research Analysis. Biol Blood Marrow Transplant 24: 1163-1171.

26. Villa D, Crump M, Panzarella T, Savage KJ, Toze CL,et al. (2013) Autologous and allogeneic stem-cell transplantation for transformed follicular lymphoma: a report of the Canadian blood and marrow transplant group. J Clin Oncol 31 1164-1171.

27. Hermine O, Hoster E, Walewski J, Bosly A, Stilgenbauer S, et al. (2016) Addition of high-dose cytarabine to immunochemotherapy before autologous stem-cell transplantation in patients aged 65 years or younger with mantle cell lymphoma (MCL Younger): a randomised, open-label, phase 3 trial of the European Mantle Cell Lymphoma Network. Lancet 388: 565-575.

28. Epperla N, Hamadani M (2017) Hematopoietic cell transplantation for diffuse large B-cell and follicular lymphoma: current controversies and advances. Hematol Oncol Stem Cell Ther 10: 277-284.

29. Myers RM, Hill BT, Shaw BE, Kim S, Millard HR, et al. (2018) Longterm outcomes among 2-year survivors of autologous hematopoietic cell transplantation for Hodgkin and diffuse large B-cell lymphoma. Cancer 124 816-825.

30. d'Amore F, Relander T, Lauritzsen GF, Jantunen E, Hagberg H, et al. (2012) Up-front autologous stem-cell transplantation in peripheral T-cell lymphoma: NLG-T-01. J Clin Oncol 30: 3093-3099.

31. Epperla N, Fenske TS, Lazarus HM, Hamadani M (2015) Post-autologous transplant maintenance therapies in lymphoid malignancies: are we there yet? Bone Marrow Transplant 50: 1393-1404

32. Le Gouill S, Thieblemont C, Oberic L, Moreau A, Bouabdallah K, et al. (2017) Rituximab after autologous stem-cell transplantation in mantle-cell lymphoma. N Engl J Med 377: 1250-1260.

33. Moskowitz $\mathrm{CH}$, Nademanee A, Masszi T, Agura E, Holowiecki J, et al. (2015) Brentuximab vedotin as consolidation therapy after autologous stem-cell transplantation in patients with Hodgkin's lymphoma at risk of relapse or progression (AETHERA): a randomised, double-blind, placebo-controlled, phase 3 trial. Lancet 385: 1853-1862.

34. Czerw T, Labopin M, Gorin NC, Giebel S, Blaise D, et al. (2016) Long-term follow-up of patients with acute myeloid leukemia surviving and free of disease recurrence for at least 2 years after autologous stem cell transplantation: a 
report from the Acute Leukemia Working Party of the European Society for Blood and Marrow Transplantation. Cancer 122: 1880-1887.

35. Wetzler M, Watson D, Stock W, Koval G, Mulkey FA, et al. (2014) Autologous transplantation for Philadelphia chromosome-positive acute lymphoblastic leukemia achieves outcomes similar to allogeneic transplantation: results of CALGB Study 10001 (Alliance). Haematologica 99: 111-115.

36. Lorch A, Bascoul-Mollevi C, Kramar A, Einhorn L, Necchi A, et al. (2011) Conventional-dose versus high-dose chemotherapy as first salvage treatment in male patients with metastatic germ cell tumors: evidence from a large international database. J Clin Oncol 29:2178-2184.

37. Chandy M (2008) Stem Cell Transplantation In India. Bone Marrow Transplantation 42: S81-S84.

38. Kumar R (2002) Stem Cell Transplantation: Indian Perspective. JIACM 3: 182-8.

39. Sharma SK, Choudhary D, Gupta N, Dhamija M, Khandelwal V, et al. (2014) Cost Of Hematopoietic Stem Cell Transplantation In India. Mediterr J Hematol Infect Dis 6: e2014046.

40. Purvish MP, Pankaj MS, Lalit EJK (2018) Hematopoetic Stem Cell Transplantation in India. In: 50 Years of Cancer Control in India: 136-149.

41. Shah CA, Karanwal A, Desai M, Pandya M, Shah R, et al. (2015) Hematopoietic Stem-Cell Transplantation in the Developing World: Experience from a Center in Western India. Journal of Oncology 2015: 9.

42. Mukhopadhyay A, Gupta P, Basak J, Chakraborty A, Bhattacharyya D, et al. (2012) Stem cell transplant: An experience from eastern India. Indian J Med Paediatr Oncol 33: 203-9.

43. Banavali SD (2009) Hematopoietic Stem Cell Transplantation: Need for Research \& Potential Applications. It's status in India. JSRM: 2009-002.

44. Dykewicz CA (2001) Hospital Infection Control in Hematopoietic Stem Cell Transplant Recipients. Emerg Infect Dis 7: 263-7.

45. Kumar L, Raju GM, Ganessan K, Shawgi S, Menon H, et al. (2003) High dose chemotherapy followed by autologus hematopoetic stem cell transplant in multiple myeloma. Nati Med J India 16: 16-21.

46. Kumar L, Ghosh J, ganessan P, Hariprasad R, Kochupillai V (2009) High dose chemotherapy with autologus stem cell transplantation for multiple myeloma: what predicts the outcome ? experience from a developing country. BMT 43: 481-489

47. Kayal S, Sharma A, lqbal S, Tejomurtula T, Cyriac SL, et al. (2014) High dose chemotherapy and autologus stem cell transplantation in multiple myeloma : A single institution experience at all india institute of medical sciences, new dehli, using non-cryopreserved peripheral blood stem cells. Clin Lymphoma Myeloma Leuk 14: 140-147.

48. Kumar L, Ganess P, Gogia A, Ghosh I, Hariprasad R (2010) high dose chemotherapy with autologus stem cell transplantation for multiple myeloma: what predicts the outcome? Biol Blood Marrow Transplant 16: S239-S240.

49. Kumar L, Ganessan P, Ghosh I, Panda D, Gogia A, et al. (2010) Autologous
Blood Stem Cell Transplantation For Hodgkin And Non-Hodgkin Lymphoma: Complications And Outcome. The National Medical Journal Of India 23: 6.

50. Nair V, Sharma A, Mishra DK (2005) Stem Cell Transplantation: Impact of High Efficiency Particulate Air (HEPA) vs. Non-HEPA BMT Unit on Transplant Outcome: A Single Centre Experience from India. Blood 106:5322.

51. Prinja S, Kaur G, Malhotra P, Jyani G, Ramachandran R, et al. (2017) CostEffectiveness of Autologous Stem Cell Treatment as Compared to Conventional Chemotherapy for Treatment of Multiple Myeloma in India. Indian J Hematol Blood Transfus 33: 31-40.

52. Raut S, Shah S, Shah K, Patel K, Talati S, et al. (2016) Improving Outcome of Hodgkins Disease with Autologous Hematopoietic Stem Cell Transplantation. Indian J Hematol Blood Transfus 32: 176-181.

53. Kumar L, Boya RR, Pai R, Harish P, Mookerjee A, et al. (2016) Autologous stem cell transplantation for multiple myeloma: Long-term results. Natl Med J India 29: 192-199.

54. Raut SS, Shah SA, Sharanangat VV, Shah KM, Patel KA, et al. (2015) Safety and Efficacy of Eltrombopag in Post-hematopoietic Stem Cell Transplantation (HSCT) Thrombocytopenia. Indian J Hematol Blood Transfus 31:413-415.

55. Shah C, Karanwal A, Desai M, Shah D, Shah RJ (2014) Autologus stem cell transplant in Multiple myeloma: Excellent safety and efficacy Possible in a Non university Hospital of Developing Country. J Hematol Thrombo Dis 2: 4.

56. Kumar L, lqbal N, Mookerjee A, Verma RK, Sharma OD, et al. (2014) Complete response after autologous stem cell transplant in multiple myeloma. Cancer Med 3: 939-946.

57. Indian Stem Cell Transplant Registry (ISCTR) Indian Stem Cell Transplant.

58. Naithani R (2018) Hematopoietic Stem Cell Transplantation in India-2017 Annual Update. Indian J Hematol Blood Transfus 34: 5-7.

59. Gupta A, Singh S, Verma SK (2015) Stem cell transplantation: Where do we stand now? JIACM 16: 236-241.

60. Kulkarni U, George B (2019) Access to hematopoietic stem-cell transplantation in India. JPGM 65: 1-4.

61. Das K, Khanna T, Agrawal N (2017) Establishing Hematopoietic Stem Cell Transplant Unit in Resource Limited Setting: A Critical Analysis of Indian Council of Medical Research 2017 Guidelines. Journal of Transplantation 2018:4.

62. Pandya SK (2008) Stem cell transplantation in India: tall claims, questionable ethics. Indian Journal of Medical Ethics 5.

63. Jotwani T (2017) National Guidelines for Stem Cell Research.

64. Tiwari AK, Arora D, Dara RC, Dorwal P, Sood N, et al. (2016) Newly established stem cell transplant program: 100 days follow-up of patients and its comparison with published Indian literature. Indian Journal of Medical and Paediatric Oncology 37: 168-173.

65. Pandit A, Garg MK, Kotwal N, Brar KS, Gundgurthi A, et al. (2015) Changes in bone mineral density and bone turnover markers in patients undergoing hematopoietic stem cell transplant. Indian J Endocr Metab 19: 393-398. 